\title{
Monetary Policy and Longer-Term Rates: An Opportunity for Greater Transparency
}

Daniel L. Thornton, Vice President and Economic Adviser

$\mathrm{T}$ he FOMC has attempted to reduce longer-term interest rates both by stating its intentions about the future path of the federal funds rate, called forward guidance, and by buying substantial quantities of longer-term assets, through what is referred to as quantitative easing. This essay discusses a potential conflict between these two methods of affecting longer-term interest rates and suggests that the FOMC could increase communication and transparency by clearly stating why it is following this two-pronged approach.

In recent years the FOMC has increasingly used forward guidance in an attempt to have a greater effect on yields of longer-maturity securities. The FOMC first adopted this approach in 2003 by stating that "policy accommodation can be maintained for a considerable period." 1 Since

December 2008, forward guidance has come in the form of the FOMC's statement that the federal funds rate is likely to remain exceptionally low for an extended period.

A theoretical basis for forward guidance is the expectations hypothesis of the term structure of interest rates $(\mathrm{EH})$, which asserts that the long-term rate is equal to the market's expectation of the average short-term rate over the holding period of the long-term asset; added to this average is a constant risk premium associated with the fact that longerterm securities have a higher degree of market risk than shorter-term securities. ${ }^{2}$ Changes in the FOMC target for the overnight federal funds rate affect longer-term interest rates to the extent that market participants expect that the change in the funds rate will persist. For example, assume the EH holds and market participants expect the FOMC's target for the funds rate to remain at, say, 5 percent for at least a year. In this case, the rate on an otherwise equivalent 1 -year bond would be 5.3 percent: that is, 5 percent due to the market's expectation of the overnight funds rate and 0.3 percent due to the risk premium. If the FOMC were to unexpectedly reduce its target for the funds rate from 5 percent to 4 percent and the market expected the FOMC to maintain the target there for at least a year, the 1-year rate would immediately drop to 4.3 percent. However, if the market expected the FOMC to increase the target back to 5 percent in six months, the 1-year rate would decrease to only $4.8 \%(1 / 2[4.0+5.0]+0.3)$. Under this same assumption, the yield on a 2-year comparable bond would decline less, a 3-year bond even less, and so on and so forth.

\section{The FOMC's two-pronged approach involves a potential conflict: forward guidance assumes a high degree of substitutability across the maturity structure, while quantitative easing assumes a low degree.}

If the $\mathrm{EH}$ is true, the longer the period of time that the market expects the FOMC to keep the funds rate at its new level, the larger will be the effect of a change in the FOMC's funds rate target on longer-term interest rates. So, one interpretation of the announcement that the funds rate is likely to be in the range of zero to $1 / 4$ percent for an "extended period" is that the FOMC hopes to reduce longer-term yields in accordance with the $\mathrm{EH}$.

More recently, the Fed has attempted to reduce longerterm interest rates directly by purchasing large quantities of longer-term securities. In late 2008 Bernanke (2008) hinted at this possibility, noting that "the Fed could purchase longer-term Treasury or agency securities on the open market in substantial quantities. This approach might influence the yields on these securities, thus helping to spur aggregate demand." 3 He noted further that it was encouraging that the Fed's announced plan to purchase up to $\$ 100$ billion in agency debt and up to $\$ 500$ billion in agency MBS "was met by a decline in mortgage rates." On March 18, 2009, the FOMC announced its intentions to purchase up to $\$ 1.75$ trillion in longer-term securities and 
on November 3, 2010, the FOMC announced that it would purchase an addition $\$ 600$ billion in longer-term Treasury securities by the end of the second quarter of 2011.

The FOMC's two-pronged approach involves a potential conflict: The forward guidance approach assumes perfect (or at least a high degree of) substitutability across the maturity structure, while the quantitative easing approach assumes a low degree of substitutability due to segmentation of markets across the maturity structure. The difference can be illustrated with a simple example. Assume the EH holds and the 5-year Treasury yield is 4 percent and the market expects that the 5 -year yield will be 4 percent for the next five years. Now assume that the 10-year Treasury yield is 4.2 percent-the average of the current and expected future 5-year yield plus a 20-basis-point risk premium. Further assume that the Fed purchases a large quantity of 10 -year securities, which initially reduces the 10 -year yield because the quantity purchased is large relative to the existing stock of 10-year bonds outstanding. As the 10-year yield falls relative to the 5-year yield, investors have an incentive to sell 10-year securities and purchase 5-year securities as the expected return to holding a sequence of two 5-year bonds is now greater than the return to holding a 10 -year bond. This will cause 10-year bond yields to rise and 5-year bond yields to fall. Of course, this process will happen across the maturity spectrum. If the EH holds, the entire structure of rates will decline but the shape of the structure determined by risk premiums will be unchanged. How much the level of the rate structure declines is determined by the size of the Fed's purchase of 10-year securities relative to the total amount of securities outstanding and the interest elasticity of demand: The larger the relative amount purchased and/or the more interest inelastic the demand, the larger the effect.

If the market for 10-year securities is perfectly segmented from the rest of the market, however, the effect of the Fed's purchase of 10-year securities would not spread beyond the 10-year yield. The reason is that investors who hold 10 -year securities prefer that maturity. Hence, they will not sell 10-year bonds and purchase 5-year bonds in spite of the economic incentive to do so. Of course, the market need not be perfectly segmented. Some of the effect of the purchase of 10-year securities could spread to some degree to securities in the neighborhood of 10 years, but not across the entire maturity spectrum. However, if this were the case, it is not clear how the Fed could affect longer-term interest rates by committing to keep the funds rate near zero for an "extended period." Hence, there is an apparent conflict between these two approaches to reducing longerterm yields.

Given the theoretical friction between these two alternative approaches to affecting longer-term yields, the FOMC could reduce uncertainty and greatly improve its communication and transparency by clearly stating why it is pursuing both of these approaches simultaneously. One possibility has been offered by Narayana Kocherlakota, president of the Federal Reserve Bank of Minneapolis, who suggested that quantitative easing might represent "another form of forward guidance about the path of the fed funds rate."4 This possibility stems from the fact that longer-term securities have more "interest rate risk" than shorter-term securities, i.e., their price changes more for any given change in the interest rate. By holding a relatively large quantity of longer-term securities, the Fed would suffer a larger capital loss if it raised interest rates. From this perspective, the large-scale purchase of longer-term securities could be seen as a commitment device, designed to enhance the effectiveness of the FOMC's forward guidance policy. Whatever the motivation, the FOMC could reduce uncertainty by explicitly stating its intentions.

${ }^{1}$ FOMC Press Release, August 12, 2003; emphasis added.

2 The EH, per se, is not mentioned in conjunction with forward guidance, most likely because the EH is resoundingly rejected (e.g., Lucio Sarno, Daniel L. Thornton, and Giorgio Valente, "The Empirical Failure of the Expectations Hypothesis of the Term Structure of Bond Yields," Journal of Financial and Quantitative Analysis, March 2007, 42(1), pp. 81-100, and the references therein). That the EH provides the theoretical basis for forward guidance is from Michael Woodford ("Optimal Monetary Policy Inertia," The Manchester School, 1999, 67(Supplement), pp. 1-35): He notes that "long rates should be determined by market expectations of future short rates" (p. 8). Elsewhere, ("Monetary Policy in the Information Economy," in Economic Policy for the Information Economy, Federal Reserve Bank of Kansas City, 2001, pp. 297-367), he is more specific, noting that "in the case of longer-term interest rates; the expectations theory of the term structure implies that these should be determined by expected future short rates" (p. 8, emphasis added).

${ }^{3}$ Ben S. Bernanke, "Federal Reserve Policies in the Financial Crisis," speech at the Greater Austin Chamber of Commerce, Austin, Texas, December 1, 2008; emphasis added;

www.federalreserve.gov/newsevents/speech/bernanke20081201a.htm.

${ }^{4}$ Narayana Kocherlakota, "Economic Outlook and the Current Tools of Monetary Policy," a speech presented at the European Economics and Financial Centre, London, September 29, 2010;

www.minneapolisfed.org/news events/pres/speech display.cfm?id=4555. 